\title{
Rapid assessment of toxicity of chlorinated aqueous solution by dissolved oxygen depletion and optical density bioassays
}

\author{
Mohammad Mehdi Amin ${ }^{1,2}{ }^{\mathbb{D}}$, Ali Fatehizadeh ${ }^{1,2} \mathbb{D}$, Nasrin Bagheri ${ }^{2,3^{*}} \mathbb{D}$ \\ ${ }^{1}$ Environment Research Center, Research Institute for Primordial Prevention of Non-communicable Diseases, Isfahan University of \\ Medical Sciences, Isfahan, Iran \\ ${ }^{2}$ Department of Environmental Health Engineering, School of Health, Isfahan University of Medical Sciences, Isfahan, Iran \\ ${ }^{3}$ Student Research Center, School of Health, Isfahan University of Medical Sciences, Isfahan, Iran
}

\begin{abstract}
Background: Chlorination of wastewater effluent with high levels of residual organic matter has been suspected to the production of toxic and hazardous disinfection by-products (DBPs) including trihalomethane (THM) compounds.

Methods: In this study, two rapid techniques including dissolved oxygen depletion (DOD) and optical density (OD) bioassays were used to evaluate the chloroform toxicity of aqueous solution. The activated sludge was collected from aeration tank of a full-scale municipal wastewater treatment plant and used as a biological inoculum. In order to achieve an active and stabilized mixed culture of bacteria, the test cultures were transferred to a fresh nutrient broth culture media every day. The influence of chloroform on DOD and OD bioassays was examined at chloroform initial concentrations of 10-1000 $\mu \mathrm{g} / \mathrm{L}$.

Results: It was revealed that the application of chloroform at concentrations of 100 and $1000 \mu \mathrm{g} / \mathrm{L}$ showed moderate and extreme toxicity, respectively, and reduced bacterial activity. The estimated chemical concentration with 50\% inhibition of bacterial activity for DOD and OD bioassays was 457 and $961 \mu \mathrm{g} / \mathrm{L}$, respectively.

Conclusion: According to the results, the wastewater effluent should use bioassays in order to evaluate the effects of DBPs where the wastewater effluent is disinfected by chlorine compounds.

Keywords: Trihalomethanes, Chloroform, Disinfection, Wastewater, Biological assay, Oxygen, Inhibition Citation: Amin MM, Fatehizadeh A, Nasrin Bagheri N. Rapid assessment of toxicity of chlorinated aqueous solution by dissolved oxygen depletion and optical density bioassays. Environmental Health Engineering and Management Journal 2020; 7(4): 271-276. doi: 10.34172/EHEM.2020.32.
\end{abstract}

Article History:

Received: 2 September 2020 Accepted: 9 October 2020

ePublished: 4 December 2020

\section{Introduction}

Chlorination is widely used for disinfection of water and wastewater around the world. During the chlorination process, chlorine reacts with natural organic matter and produces hazardous disinfection by-product (DBPs) (1, 2). One of the main groups of DBPs are trihalomethanes (THMs). The most well-known THMs include chloroform $\left(\mathrm{CHCl}_{3}\right)$, bromodichloromethane $\left(\mathrm{CHBrCl}_{2}\right)$, chlorodibromomethane $\left(\mathrm{CHBr}_{2} \mathrm{Cl}\right)$, and bromoform $\left(\mathrm{CHBr}_{3}\right)(2,3)$. THMs, especially chloroform, have been more studied among all DBPs, because of its frequency (4).

Disinfected wastewater effluents have a negative effect on aquatic organisms as well as on the balance of the aquatic ecosystem and the receptor water body (5). Recent epidemiological studies have shown that THMs have adverse impacts such as sudden abortion, stillborn, and disorder in reproductive. Some researchers have reported that there is a correlation between THMs and colorectal and bladder cancers $(4,6,7)$. Chloroform is a dominant THM that was identified by Rook in 1974 (8). It causes teratogenicity, hepatotoxicity, nephrotoxicity, and damage to the liver, kidneys, and central nervous system (8). Toxicity of chlorine itself is removed by dechlorination but this process does not remove DBPs (9). More than 600 DBPs have been identified but the toxicity of a few of them has been evaluated (10).

The chemical analyses just determine the components and concentration of contaminants that release into the environment but biological analyses can directly reflect the effect of contaminants on organisms (11). Bioassay has been used for assessment of environmental contaminant. Bioassay is a test in which living tissues, organism or a group of organisms are exposed with contaminants and the effects of chronic or acute toxicity on them are assessed (12).

There are several bioassay methods that evaluate various classes of toxicity including acute toxicity, cytotoxicity, 
genotoxicity, estrogenic activity and so on (13). Fish, bacteria, crustaceans, and alga have been used in the bioassay methods $(14,15)$. Most of the traditional acute toxicity tests were costly, time-consuming, and ethically questionable $(15,16)$.

As bacteria are cheap to cultivate, grow rapidly, technically simple, require low space compared with fish bioassay, available and contain enzymatic and physiological processes, also found in larger organisms, they are good bioassay tools. Bacteria respond more than most other organisms to change their condition and sensitive to toxicity compound (17).

Many researchers studied the toxicity effects of different contaminants by bioassay. Residual chlorine in water affects the behavioral responses of Daphnia magna (18). Based on the toxicity categories generated by the United States Environmental Protection Agency, acute and chronic toxicity of some of the DBPs for Daphnia Magna, Cyprinodont Variegatus, and Isochrysis Galbana is slightly or non-toxic (19). The results obtained from SOS/ Umu test showed that chlorination of drinking water can damage deoxyribonucleic acid (DNA) (20).

Chlorination of wastewater effluent had ecotoxicity effects but did not have a toxic impact on Daphnia Magna or any ecotoxicity by the THMs (21). To evaluate the toxicity of linden, mercury, and wastewater, dissolved oxygen depletion (DOD) and optical density (OD) bioassays were used. It was revealed that DOD and OD bioassays can evaluate the toxicity of the above-mentioned contaminants (17). Conventional techniques were precise but expensive, and need special equipment and trained personnel (16).

Due to the challenges of toxicity assessment, almost no studies have provided a complete toxicity assessment for chlorinated aqueous solution up to now. In this study, the toxicity of chloroform as an indicator of THMs was assessed using DOD and OD as rapid and user-friendly toxicity bioassays. Using these experimentally determined toxicity bioassays, the toxicity of chloroform on the mixed culture of bacteria was interpreted by AQ and AR indices.

\section{Materials and Methods \\ Preparation of bacterial inoculum}

The activated sludge was collected from aeration tank of a full-scale municipal wastewater treatment plant (Isfahan South WWTP, Isfahan, Iran) and was used as a biological inoculum. At first, approximately $1 \mathrm{ml}$ of the activated sludge was transferred onto the prepared nutrient agar plates and incubated at $37^{\circ} \mathrm{C}$ for $24 \mathrm{~h}$. Then, the grown colonies were suspended into $150 \mathrm{~mL}$ of nutrient broth culture and incubated at $37^{\circ} \mathrm{C}$ for 24 hours. After incubation, in order to provide the active and stabilized mixed culture of bacteria and keep the bacteria in the logarithmic growth phase, about $1 \mathrm{~mL}$ of the suspension of nutrient broth culture and bacteria were transferred to a fresh nutrient broth every day for two weeks. According to the previous study, Pseudomonas, Micrococcus, Bacillus, Aeromonas, and Nitrobacter spp., are the dominant species of bacteria in the activated sludge (22).

\section{Toxicity assessment methods}

In this study, two rapid techniques including DOD and OD bioassays were used to evaluate the chloroform toxicity of aqueous solution according to the methods described by Salama and Salem (17).

\section{DOD experiment}

Before experiments, the OD of the prepared bacteria inoculum was adjusted to 0.18 to 0.2 at a wavelength of $600 \mathrm{~nm}$ with dilution in distilled water. After preparation of synthetic chloroform solution with the initial concentration of 100 to $1000 \mu \mathrm{g} / \mathrm{L}, 50 \mathrm{ml}$ of bacteria inoculum was mixed with $300 \mathrm{~mL}$ of test solution and transferred to sterile glass flasks. The amount of dissolved oxygen (DO) was monitored every 30 seconds with a dissolved oxygen sensor (model 5740 sc membrane, $\mathrm{HACH}$, USA) until DO amount reached $50 \%$ of the initial DO amount.

\section{OD experiment}

The OD microbial bioassay was performed on synthetic wastewater containing chloroforms. The reduction of OD of the bacterial inoculum was measured using a spectrophotometer (2 OD spectrophotometer, Milton Roy Company). For this purpose, a serial solution of chloroform with concentrations of 10 to $1000 \mu \mathrm{g} / \mathrm{L}$ was prepared. The experiments were performed by adding 100 $\mathrm{mL}$ of chloroform solution to $250 \mathrm{~mL}$ sterile glass flasks containing $100 \mathrm{~mL}$ of sterile nutrient broth. Then, $0.1 \mathrm{~mL}$ of bacterial inoculum were suspended into the abovementioned sterile glass flasks to obtain the OD of 0.18 to 0.2 at a wavelength of $600 \mathrm{~nm}$, and then, incubated at $37^{\circ} \mathrm{C}$ for 24 hours. After incubation, the produced turbidity value in the blank and test solutions was measured at a wavelength of $600 \mathrm{~nm}$.

\section{Mathematics}

In the DOD experiments, the activity quotient $(A Q)$ was calculated according to Eq. (1).

$A Q(\%)=\left(\frac{T_{50, B}}{T_{50, T}}\right) \times 100$

Where, $A Q$ is the activity quotient, $T_{50, B}$ is the time required for $50 \%$ reduction of DO in blank solution, and $T_{50, T}$ is the time required for $50 \%$ reduction of DO in test solution. The general guidelines for interpretation of AQ and evaluation of toxicity level are summarized in Table 1.

In addition, Eq. (2) was used to compute the reduction of bacterial activity in the OD experiments.

$A R(\%)=\left(1-\frac{A_{T}}{A_{B}}\right) \times 100$ 
Table 1. Guidelines for interpretation of AQ

\begin{tabular}{lc}
\hline AQ Value (\%) & Toxicity Degree \\
\hline 100 & Non-toxic \\
\hline $80-94$ & Slightly toxic \\
\hline $50-79$ & Moderately toxic \\
\hline$<59$ & Extremely toxic \\
\hline
\end{tabular}

Where $A R$ is the percentage of bacterial activity reduction, $A_{B}$ is the bacterial absorption in blank solution, and $A_{T}$ is the bacterial absorption in test solution.

\section{Statistical analysis}

To evaluate the effect of chloroform on the bacterial inoculum, the chemical concentration with 50\% inhibition of bacterial activity $\left(\mathrm{EC}_{50}\right)$ indicator was used. The standard protocols were used to calculate the dose-response relationships and the obtained data were analyzed using Probit analysis by IBM SPSS statistics version 16 for windows to assess the $\mathrm{EC}_{50}$ concentration.

\section{Results}

Toxicity assessment by DOD technique

The obtained data on DO depletion during DOD experiments are illustrated in Figure 1.

As illustrated in Figure 1, the time duration for DO concentration depletion in blank test was $68 \mathrm{~min}$. With adding chloroform and increasing its concentration, the time duration for DO concentration depletion was increased. When chloroform at concentration of 100 and $1000 \mu \mathrm{g} / \mathrm{L}$ was examined, time duration for DO concentration depletion expanded to $125 \mathrm{~min}$ and 416 min, respectively. This condition revealed that the duration of responses depending on toxicant concentration. The calculated $A Q$ in terms of $T_{50, B}$ and $T_{50, T}$ are presented in Figure 2.

As seen in Figure 2, with increasing the chloroform concentration in test solution, the AQ value was reduced. The AQ of blank test was equal to $100 \%$, indicating a nontoxic condition. When the experiment was conducted at chloroform concentrations of 100 and $1000 \mu \mathrm{g} / \mathrm{L}$, the AQ values were obtained to be $54.4 \%$ and $16.3 \%$, respectively. According to Table 1, the toxicity degree of chloroform at concentrations of 100 and $1000 \mu \mathrm{g} / \mathrm{L}$ were moderately and extremely toxic, respectively. The dose-response graphs for different concentrations of chloroform on the AQ values are shown in Figure 3.

As shown in Figure 3, with increasing the concentration of chloroform, the $A Q$ value was reduced, and the $\mathrm{EC}_{50}$ concentration for chloroform by DOD technique was 457 $\mu \mathrm{g} / \mathrm{L}$.

\section{Toxicity assessment by OD technique}

The variation of OD during OD experiments is shown in Figure 4.

As seen in Figure 4, with increasing the chloroform concentration in OD experiments, the OD of bacteria was reduced. The higher and lower optical densities were related to blank and test solution of $1000 \mu \mathrm{g} / \mathrm{L}$, respectively. The variation of $A R$ values during $O D$ experiments as the function of chloroform concentration is illustrated in Figure 5.

As illustrated in Figure 5, with increasing the chloroform concentration, the bacteria activity was reduced. When the initial chloroform concentration increased from 0 to 1000 $\mu \mathrm{g} / \mathrm{L}$, the OD of bacterial inoculum decreased from $52 \%$ to $25 \%$. The application of chloroform at concentrations of $10 \mu \mathrm{g} / \mathrm{L}$ led to a decrease (15\%) in the bacterial activity. The graphs of dose-response as the function of chloroform concentration are shown in Figure 6.

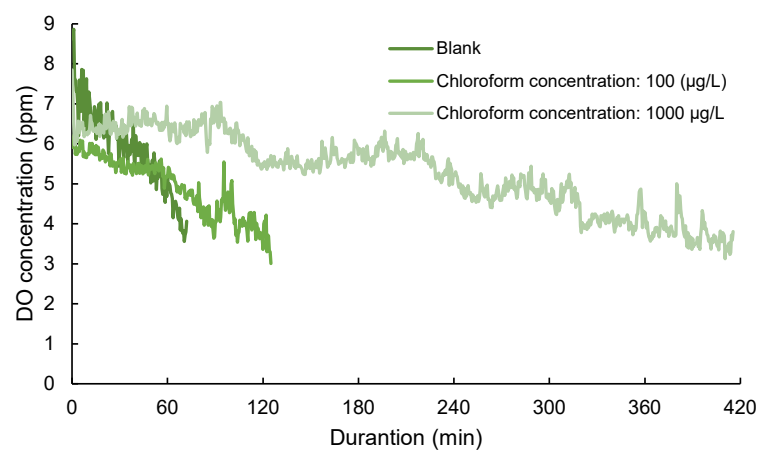

Figure 1. DO profile during DOD experiment.

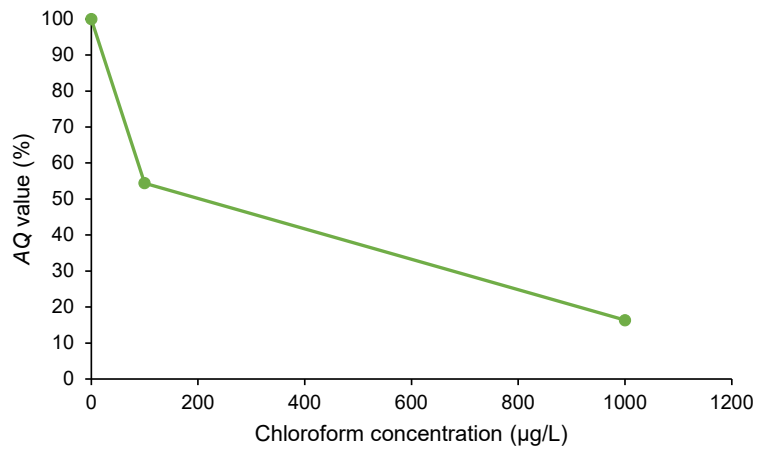

Figure 2. Activity quotients for chloroform during DOD experiment.

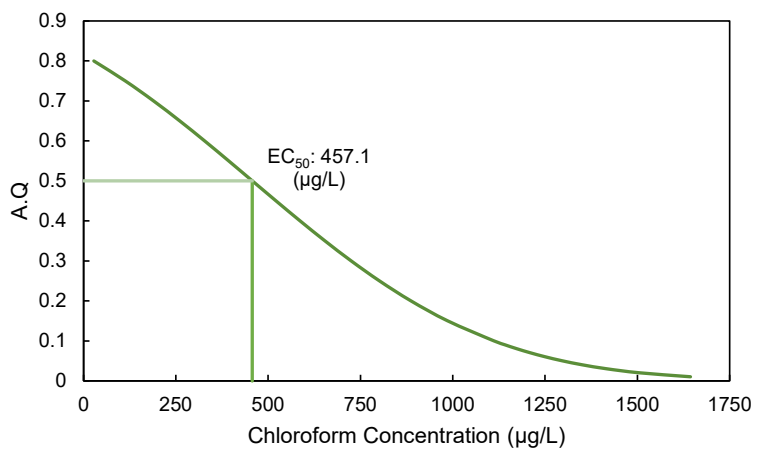

Figure 3. Dose-response curve of DOD. 


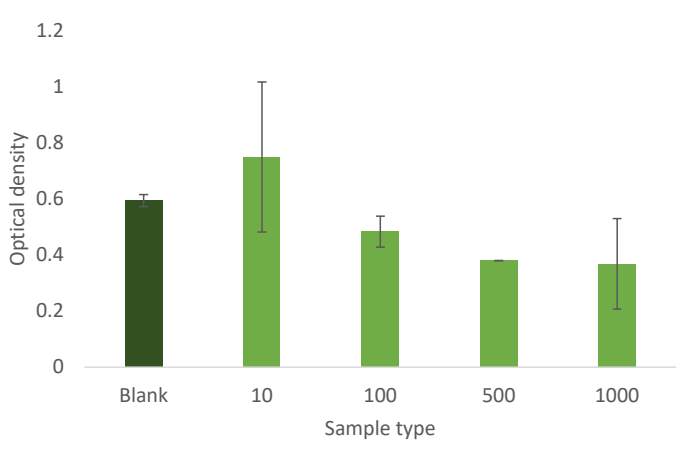

Figure 4. Variation of optical density during OD experiment.

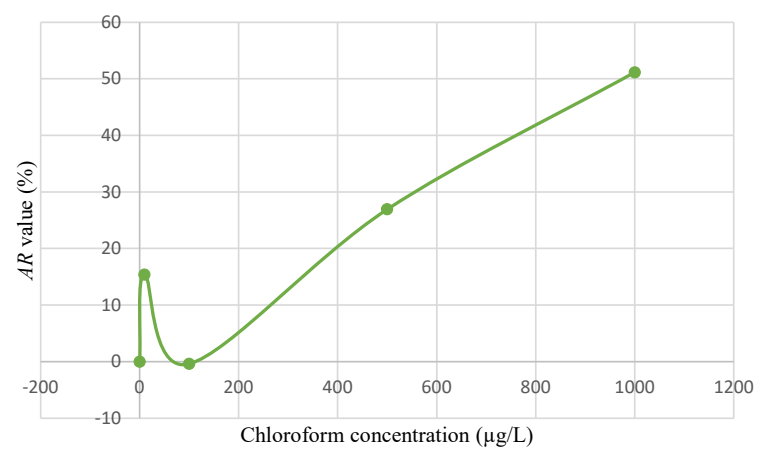

Figure 5. Activity reduction for chloroform during OD experiment.

According to Figure 6, the $\mathrm{EC}_{50}$ value of chloroform estimated for a bacterial consortium in OD technique was $961 \mu \mathrm{g} / \mathrm{L}$.

\section{Discussion}

The findings demonstrated that with increasing the chloroform concentration, the time duration for DO concentration depletion in DOD method was increased (Figures 1 and 2). This condition revealed that the duration of responses depending on the toxicant concentration $(17,23)$. The higher concentrations of chloroform caused lower depletion of DO (23). The application of higher concentrations of chloroform caused a significant reduction in the AQ value and noticeable toxicity for bacteria (24). According to the results of other studies, some pollutants allowed dissolved oxygen deplition and DOD methods to assay the toxicity of some heavy metals and trichloroacetic acid (23). The $\mathrm{EC}_{50}$ for chloroform by DOD technique was obtained to be $457 \mu \mathrm{g} / \mathrm{L}$. Cao et al evaluated the toxicity of chlorinated effluents on some organisms and reported that chlorination evaluated acute toxicity and genotoxicity of wastewater and mortality of invertebrates. They also reported that the $\mathrm{EC}_{50}$ for chloroform on Dafnia magna was equel to $573.01 \mathrm{ppm}$ (24), indicating that chloroform was more toxic for consortium of D. magna, and DOD method is sensitive enough to measure the toxicity of chloroform. In another study by $\mathrm{Wu}$ et al on the effects of THMs on Q67 luminescent bacterium, the $\mathrm{EC}_{50}$ was obtained to be $318 \mu \mathrm{g} / \mathrm{L}$ (25), confirming the toxicity of THMs.

During OD method, the higher concentrations of chloroform led to a decrease in the OD of bacteria, however, the variation of $A R$ value of blank was slight. Recent studies have demonstrated that several pollutants had a toxic function for aquatic microorganisms and with increasing the concentration of contaminants, their activity reduced (15). The $\mathrm{EC}_{50}$ of chloroform for a consortium of bacteria in OD technique was $961 \mu \mathrm{g} / \mathrm{L}$ (Figure 6). Zare et al (22) evaluated the toxicity of industrial wastewater containing heavy metals on the bacterial consortium extracted from sequencing batch reactor (SBR) and reported that the $\mathrm{EC}_{50}$ and NOEC values were 6.43 and $1.35 \mathrm{ml} / \mathrm{L}$, respectively, indicating that bacterial consortium was a suitable tool for bioassay.

Da Costa et al (26) evaluated the toxicity of secondary effluent disinfected with chlorine on aquatic organisms and found that effluent disinfected with chlorine was toxic for Daphnia similis and Ceriodaphnia silvestrii (cladocerans) and reported that the calculated $E C_{50}$ values were 0.04 and $1.28 \mathrm{mg} \mathrm{Cl} / \mathrm{L}$, respectively (26). Based on the obtained results, the DOD toxicity assay was more sensitive than the OD toxicity assay so that it showed the toxicity effect at lower toxic concentrations, which is consistent with the results of other studies (17).

Recently researchers have found that chloroform decreases methylation that leads to the overexpression of proto-oncogene. Generally, it was suggested that THMs cause a decline in the methylation of the c-myc protooncogene, which lead to the uncontrolled expression of gene sequence (4). Direct contact by oral gavage with chloroform caused tumorigenesis (4) and hepatocellular tumor in mice; and in combination with inhalation, produced renal tumors in rats (7).

Chloroform did not cause mutations in bacteria and failed to induce chromosome damage or sister-chromatid exchanges in human lymphocytes. There is no evidence indicating that chloroform is capable of alkylating DNA (27). Researchers have shown that chloroform increased the proliferating cell nuclear antigen-labeling index and reduced the level of 5-methylcytosine in hepatic DNA in

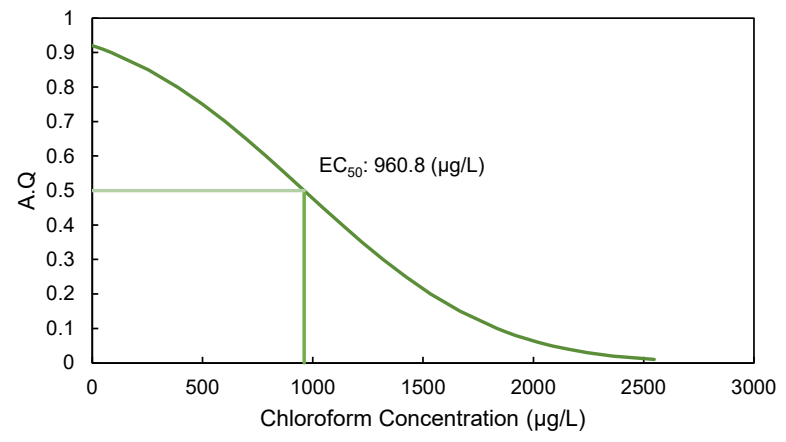

Figure 6. Curve of dose-response for OD experiments. 
B6C3F1 mouse (28).

\section{Conclusion}

In the present study, the toxicity of chloroform as an indicator of THMs was assessed by DOD and OD as the rapid and user-friendly toxicity bioassays. In addition, the toxicity of chloroform on the mixed culture of bacteria was interpreted by the $\mathrm{AQ}$ and $\mathrm{AR}$ indices. According to the results, the expanded time for DO concentration depletion was observed by increasing the concentration of chloroform, which is consistent with dissimilar experimental results indicating that the OD of bacteria was decreased with increasing the chloroform concentration. The $\mathrm{EC}_{50}$ values estimated for DOD and OD bioassays were 457 and $961 \mu \mathrm{g} / \mathrm{L}$, respectively. The application of chloroform at concentrations of 100 and $1000 \mu \mathrm{g} / \mathrm{L}$ showed moderate and extreme toxicities, respectively. Compared to OD bioassay, the DOD bioassay was more sensitive so that it could show the toxicity effect at lower toxic concentrations.

\section{Acknowledgments}

The authors would like to gratitude Isfahan University of Medical Sciences, Isfahan, Iran, for its financial support (project No. 396732).

\section{Ethical issues}

The authors certify that this manuscript is the original work of the authors, all data collected during the study are presented in this manuscript, and no data from the study has been or will be published elsewhere separately (Ethical code: IR.MUI.REC.1369.3.732).

\section{Competing interests}

The authors declare that they have no conflict of interests.

\section{Authors' contributions}

All authors contributed and participated in the data collection, analysis, and interpretation. Also, they critically reviewed, refined, and approved the manuscript.

\section{References}

1. Sun YX, Wu QY, Hu HY, Tian J. Effects of operating conditions on THMs and HAAs formation during wastewater chlorination. J Hazard Mater 2009; 168(2-3): 1290-5. doi: 10.1016/j.jhazmat.2009.03.013.

2. Pantelaki I, Voutsa D. Formation of iodinated THMs during chlorination of water and wastewater in the presence of different iodine sources. Sci Total Environ 2018; 613-614: 389-97. doi: 10.1016/j.scitotenv.2017.09.072.

3. Xue R, Shi H, Ma Y, Yang J, Hua B, Inniss EC, et al. Evaluation of thirteen haloacetic acids and ten trihalomethanes formation by peracetic acid and chlorine drinking water disinfection. Chemosphere 2017; 189: 34956. doi: 10.1016/j.chemosphere.2017.09.059.

4. Hung YC, Waters BW, Yemmireddy VK, Huang C-H. pH effect on the formation of THM and HAA disinfection byproducts and potential control strategies for food processing. J Integr Agric 2017; 16(12): 2914-23. doi: 10.1016/s2095-3119(17)61798-2.

5. Luan X, Liu X, Fang C, Chu W, Xu Z. Ecotoxicological effects of disinfected wastewater effluents: a short review of in vivo toxicity bioassays on aquatic organisms. Environ Sci Water Res Technol 2020; 6(9): 2275-86. doi: 10.1039/ d0ew00290a.

6. Kiani R, Sobhanardakani S, Cheraghi M. Investigation of trihalomethanes in drinking water of Abbas Abad water treatment plant. Scientific Journal of Hamadan University of Medical Sciences 2017; 24(1): 72-9. doi: 10.21859/hums240110. [In Persian].

7. Richardson SD, Plewa MJ, Wagner ED, Schoeny R, Demarini DM. Occurrence, genotoxicity, and carcinogenicity of regulated and emerging disinfection by-products in drinking water: a review and roadmap for research. Mutat Res 2007; 636(1-3): 178-242. doi: 10.1016/j. mrrev.2007.09.001.

8. Musikavong C, Wattanachira S, Marhaba TF, Pavasant P. Reduction of organic matter and trihalomethane formation potential in reclaimed water from treated industrial estate wastewater by coagulation. J Hazard Mater 2005; 127(1-3): 58-67. doi: 10.1016/j.jhazmat.2005.06.037.

9. Watson K, Shaw G, Leusch FD, Knight NL. Chlorine disinfection by-products in wastewater effluent: bioassaybased assessment of toxicological impact. Water Res 2012; 46(18): 6069-83. doi: 10.1016/j.watres.2012.08.026.

10. Fukushima T, Hara-Yamamura H, Urai M, Kasuga I, Kurisu F, Miyoshi T, et al. Toxicity assessment of chlorinated wastewater effluents by using transcriptome-based bioassays and Fourier transform mass spectrometry (FTMS) analysis. Water Res 2014; 52: 73-82. doi: 10.1016/j. watres.2014.01.006.

11. Ma XY, Wang XC, Ngo HH, Guo W, Wu MN, Wang $\mathrm{N}$. Bioassay based luminescent bacteria: interferences, improvements, and applications. Sci Total Environ 2014; 468-469: 1-11. doi: 10.1016/j.scitotenv.2013.08.028.

12. Chavan M, Thacker NP, Tarar JL. Toxicity evaluation of pesticide industry wastewater through fish bioassay. IRAInternational Journal of Applied Sciences 2016; 3(3): 331-9. doi: 10.21013/jas.v3.n3.p3.

13. Chai Q, Hu A, Qian Y, Ao X, Liu W, Yang H, et al. A comparison of genotoxicity change in reclaimed wastewater from different disinfection processes. Chemosphere 2018; 191: 335-41. doi: 10.1016/j.chemosphere.2017.10.024.

14. Harbi K, Makridis P, Koukoumis C, Papadionysiou M, Vgenis T, Kornaros M, et al. Evaluation of a battery of marine species-based bioassays against raw and treated municipal wastewaters. J Hazard Mater 2017; 321: 537-46. doi: 10.1016/j.jhazmat.2016.09.036.

15. Rotini A, Manfra L, Spanu F, Pisapia M, Cicero AM, Migliore L. Ecotoxicological method with marine bacteria Vibrio anguillarum to evaluate the acute toxicity of environmental contaminants. J Vis Exp 2017; (123): 55211. doi: 10.3791/55211.

16. Ma H, Yong D, Kim H, Zhang Z, Ma S, Han X. A ferricyanidemediated activated sludge bioassay for determination of the toxicity of water. Electroanalysis 2016; 28(3): 580-7. doi: 10.1002/elan.201500433.

17. Salama MS, Salem AA. Comparison of three microbial 
bioassay techniques for marine bacteria. Environ Int 1990; 16(1): 17-22. doi: 10.1016/0160-4120(90)90200-p.

18. Zeng Y, Fu Xe, Ren Z. The effects of residual chlorine on the behavioural responses of Daphnia magna in the early warning of drinking water accidental events. Procedia Environ Sci 2012; 13: 71-9. doi: 10.1016/j. proenv.2012.01.006.

19. Fisher D, Yonkos L, Ziegler G, Friedel E, Burton D. Acute and chronic toxicity of selected disinfection byproducts to Daphnia magna, Cyprinodon variegatus, and Isochrysis galbana. Water Res 2014; 55: 233-44. doi: 10.1016/j. watres.2014.01.056.

20. Zeng Q, Zhang SH, Liao J, Miao DY, Wang XY, Yang P, et al. Evaluation of genotoxic effects caused by extracts of chlorinated drinking water using a combination of three different bioassays. J Hazard Mater 2015; 296: 23-9. doi: 10.1016/j.jhazmat.2015.04.047.

21. Park KY, Choi SY, Lee SH, Kweon JH, Song JH. Comparison of formation of disinfection by-products by chlorination and ozonation of wastewater effluents and their toxicity to Daphnia magna. Environ Pollut 2016; 215: 314-21. doi: 10.1016/j.envpol.2016.04.001.

22. Zare MR, Amin MM, Nikaeen $M$, Zare $M$, Bina B, Fatehizadeh A, et al. Simplification and sensitivity study of Alamar Blue bioassay for toxicity assessment in liquid media. Desalin Water Treat 2016; 57(23): 10934-40. doi:
$10.1080 / 19443994.2015 .1040853$

23. Bauer NJ, Seidler RJ, Knittel MD. A simple, rapid bioassay for detecting effects of pollutants on bacteria. Bull Environ Contam Toxicol 1981; 27(5): 577-82. doi: 10.1007/ bf01611066.

24. Cao N, Yang M, Zhang Y, Hu J, Ike M, Hirotsuji J, et al. Evaluation of wastewater reclamation technologies based on in vitro and in vivo bioassays. Sci Total Environ 2009; 407(5): 1588-97. doi: 10.1016/j.scitotenv.2008.10.048.

25. Wu MN, Wang XC, Ma XY. Characteristics of THMFP increase in secondary effluent and its potential toxicity. J Hazard Mater 2013; 261: 325-31. doi: 10.1016/j. jhazmat.2013.07.022.

26. da Costa JB, Rodgher S, Daniel LA, Espíndola EL. Toxicity on aquatic organisms exposed to secondary effluent disinfected with chlorine, peracetic acid, ozone and UV radiation. Ecotoxicology 2014; 23(9): 1803-13. doi: 10.1007/ s10646-014-1346-z.

27. Wolf DC, Butterworth BE. Risk assessment of inhaled chloroform based on its mode of action. Toxicol Pathol 1997; 25(1): 49-52. doi: 10.1177/019262339702500110.

28. Coffin JC, Ge R, Yang S, Kramer PM, Tao L, Pereira MA. Effect of trihalomethanes on cell proliferation and DNA methylation in female B6C3F1 mouse liver. Toxicol Sci 2000; 58(2): 243-52. doi: 10.1093/toxsci/58.2.243. 